\title{
Bias in Higher Education in the Era of Globalization: A Gender Perspective
}

\author{
Ashutosh Sinha ${ }^{1}$, Alka Sinha ${ }^{2}$ \\ ${ }^{I}$ Reader, Department of Economics and Rural Development, Dr. R.M.L. Avadh University, Faizabad,India. \\ ${ }^{2}$ Lecturer, Department of Economics, Isabella Thoburn College, Lucknow, India.
}

\begin{abstract}
Gender based bias against women is prevalent everywhere from times immemorial. The paper makes an attempt to study discrimination against Indian women in attainment of higher education in general and technical and professional education in particular in the era of economic liberalization and globalization. The phenomenon of globalization is supposed to have completely transformed higher education scenario in the developing world to emerge it as business. This in turn has completely altered the selection of subjects conducive for employment devaluing humanities and social sciences which were more popular among women in general.

For studying gender based disparity data from different sources mainly from Census of India, University Grants Commission and Ministry of H.R.D. have been analyzed. The analysis relates to educational infrastructure including women colleges, and female enrolment, in both the technical and non-technical categories in both the pre and post liberalization period to facilitate comparison.

The findings of the study suggest bias against women in matters related to higher education. The discrimination was found more in professional and technical category in comparison to non-technical category. Bias against females increased in the era of globalization. This calls for immediate attention and corrective measures in the higher education policy so as to make it more responsive for female education with special consideration for the rural sector females in the era of globalization.
\end{abstract}

Keywords: Educational Infrastructure, Female Enrolment, Female Degree Holders, Higher Education.

\section{Introduction}

Gender based bias or discrimination is universal and enduring. From times immemorial women have been discriminated against in all walks of life. It is true that it has been universally condemned but it is equally true that in the modern society of today discrimination on account of sex is practiced everywhere in the world. The biased behavior against women may broadly apply to both education and employment, where the former directly affects the latter. It is generally held that on account of social reasons women are denied equal access to education as men. The poor paying capacity of parents also leads to discriminatory behavior against daughters in matters of education when expenditure on education becomes high. In developing countries like India education in general and higher education in particular has become very expensive in the era of globalization. In case of shortage of funds parents prefer to spend on son's education at the cost of daughter's education.

The social benefits of education are quite obvious and hence do not require emphasis (Appleton and Horsnell, 1990). At the same time it is also important to realize that people acquire education not only for its intrinsic value but also for enhancing their capabilities to suit the requirements of the labour market (Kingdon, 1997). The latter consideration for acquiring education has become the primary consideration in the era of globalization.

The process of globalization has completely changed the higher education scenario in the country. The relationship between the government and the higher education imparting institutions has fully altered. There is a steep fall in government funding for higher education and simultaneous increase in reliance of educational institutions for resources on market, industry and students (Clarke,1996; Marginson, 2000). This has completely made higher education a business and profit maximization has become the main motive of educational institutions. Unfortunately, things do not end here. Globalization has not only made higher education a very expensive proposition but has also induced massive changes in the structure of courses, their content and even research. Professional courses are in high demand and institutions as well as students are losing interest in traditional courses. Earlier, the educational institutions with more financial support from the government tried to strike a balance across disciplines but now they are responding only to the signals of the market (Nayyar, 2007).

Thus the world has become a global market where a direct nexus between the industry, corporate world and higher education has completely changed the skill requirements for employment. The position of women has become more vulnerable as a result of the devaluation of subjects in the humanities and social sciences, which were popular among them (Chanana, 2007). Under the situation even the spread of higher education has 
not helped the cause of females in the country (Sahni and Shankar, 2012). How far, women are successful in adapting to the challenges posed by post 1991 economic liberalization and globalization of the Indian economy is extremely important to know, keeping in view the seriousness of the matter.

For a complete study of gender based disparity in higher education in the era of globalization the study of educational infrastructure, including women institutions, female enrolments in both technical and nontechnical category and more importantly comparison with males is required. The following analysis makes an attempt in this direction.

\section{Educational Institutions in India}

For imparting education irrespective of gender, the main requirement is of a sound educational infrastructure. There should be adequate number of educational institutions to cater the needs of the growing population. The requirement of professional and technical institutions is all the more important for professional and technical workers. The table 1 provides information in this regard for the pre liberalization period (1981 to 1991) and the post liberalization period (1991 to 2001).The data reveals that the numbers of educational institutions have grown all along during the three decades, from 1981 to 2001. This is applicable to both general educational institutions as well as professional and technical institutions. The figures of professional and technical institutions are inferior in comparison to general educational institutions.

For professional and technical institutions the figures are particularly low for agriculture and forestry and veterinary science. This is an area of serious concern considering the importance of these sectors in the national economy. The figures of engineering, technology and architecture and medicine are better in comparison to other fields indicating the demand for such type of education which may be linked to job requirements in the IT sector and medical and health fields. The figures for teachers training are also very high suggesting increasing demand for teachers. On the whole the number of educational institutions has risen faster in the post-liberalization period as compared to pre-liberalization period which may be because of increased liberalization accompanied by globalization of the national economy resulting in the growth of the demand for skilled work force.

Table 1

Number of Educational Institutions Imparting Higher Education

\begin{tabular}{|c|c|c|c|}
\hline Type & 1981 & 1991 & 2001 \\
\hline University/Deemed Universities/Institutions of National Importance & 132 & 184 & 272 \\
\hline Research Institutions & - & 49 & 79 \\
\hline Degree Standard and above General Educational Institutions & 3421 & 4862 & 8737 \\
\hline \multicolumn{4}{|l|}{ Degree Standard and above Professional and Technical Institutions } \\
\hline (a)Agriculture and Forestry & 61 & 80 & 102 \\
\hline (b)Engineering, Technology and Architecture & 171 & 282 & 838 \\
\hline (c) Medicine** & 249 & 346 & 725 \\
\hline (d)Veterinary Science & 22 & 37 & 50 \\
\hline (e)Teacher's Training & 341 & 474 & 846 \\
\hline (f)Others $* * *$ & - & 673 & 2004 \\
\hline
\end{tabular}

Note $\quad: *$ As on September 30 of the relevant year.

** Medicine includes Allopathic, Homoeopathy, Ayurveda, Unani, Dental, Pharmacy, Nursing and Physiotherapy.

*** Includes Law, Management, MCA/IT, Agriculture, etc.

Source: 1. Ministry of H.R.D., Department of Secondary and Higher Education Selected educational

2. Statistical Abstract-2003 (for Agriculture \& Veterinary Colleges).

\section{I. Female Educational Institutions in India}

Despite the fact that most of the institutions, specially at the higher level do not bar admission to girls/women, yet due to social considerations and other reasons institutions exclusively for female students are also required if female education is to be given priority. Tables 2(a) and 2(b) give information in this regard.

As per information of table 2(a) for the period 1975-76 to 2005-06 the numbers of women colleges have risen in absolute terms all along. The numbers of women colleges which were 528 in 1975-76, were 874 in 1990-91 and 3432 in 2009-10. However, when we look at their share in the total then the figures are not very encouraging. In percentage terms the figures of women colleges have come down from $12.36 \%$ in $1975-76$ to 
$11.9 \%$ in 1990-91. In the year 2005-06 the percentage of women colleges out of total was $10.53 \%$ which was lowest. This all suggests that though the number of colleges in the higher education exclusively for women has increased, the number of co-educational institutions have risen much faster keeping the percentage of women colleges down.

Table 2(a)

Number of Colleges (Total \& Women Colleges) in India Since 1975-76

\begin{tabular}{|c|c|c|c|}
\hline Year & $\begin{array}{c}\text { Total Number of } \\
\text { Colleges }\end{array}$ & $\begin{array}{c}\text { Number of Women } \\
\text { Colleges }\end{array}$ & $\begin{array}{c}\text { \%of Women } \\
\text { Colleges }\end{array}$ \\
\hline $1975-76$ & 4272 & 528 & 12.36 \\
\hline $1980-81$ & 4722 & 609 & 12.9 \\
\hline $1985-86$ & 5816 & 741 & 12.74 \\
\hline $1990-91$ & 7346 & 874 & 11.9 \\
\hline $1995-96$ & 9252 & 1146 & 12.39 \\
\hline $2000-2001$ & 12806 & 1578 & 12.32 \\
\hline $2005-2006$ & 18064 & 1902 & 10.53 \\
\hline $2009-2010$ & 31324 & 3432 & \\
\hline
\end{tabular}

Source: University Grants Commission,

(1)Basic facts and Figures, $1995-96$ to 2000-2001

(2)Annual Reports (relevant years).

Table 2(b) gives the compound rate of growth of women colleges in the pre-liberalization period (1975-76 to 1990-91) and the post liberalization period (1990-91 to 2009-10). The growth rate in the post liberalization period is faster by $2.9 \%$ in comparison to the growth rate of pre-liberalization period.

Table 2 (b)

Compound Rate of Growth of Female Colleges in India

\begin{tabular}{|c|c|}
\hline $\begin{array}{c}\text { Pre-Liberalization } \\
\text { (1975-76 to 1990-91) }\end{array}$ & $\begin{array}{c}\text { Post-Liberalization } \\
\text { (1990-91 to 2009-10) }\end{array}$ \\
\hline $3.5 \%$ & $6.4 \%$ \\
\hline
\end{tabular}

Source : Computed from Table 2(a)

\section{Female Enrolment in Higher Education}

Education of females at higher level is very essential if they have to compete with men in the labour market. Women enrolment figures in higher education are provided in the table 3(a) from the year 1975-76 to 2009-10.

Table 3(a)

All India Growth of Students Enrolment, Women Enrolment from 1975-76 to 2009-2010 in Higher

Education

\begin{tabular}{|l|c|c|c|}
\hline \multicolumn{4}{|c|}{ (Excludes Pre-university/Intermediate/Pre-professional Level) } \\
\hline Year & $\begin{array}{l}\text { Total Enrolment(all levels } \\
\text { inclusive) }\end{array}$ & $\begin{array}{l}\text { Number of Women } \\
\text { Enrolled }\end{array}$ & \% of Women \\
\hline $\mathbf{1 9 7 5 - 7 6}$ & 2426109 & 595162 & 24.5 \\
\hline $\mathbf{1 9 8 0 - 8 1}$ & 2752437 & 748525 & 27.2 \\
\hline $\mathbf{1 9 8 5 - 8 6}$ & 3605029 & 1067484 & 29.6 \\
\hline $\mathbf{1 9 9 0 - 9 1}$ & 4924868 & 1436887 & 29.2 \\
\hline $\mathbf{1 9 9 5 - 9 6}$ & 6574005 & 2363607 & 35.9 \\
\hline $\mathbf{2 0 0 0 - 2 0 0 1}$ & 8399443 & 3306410 & 39.4 \\
\hline $\mathbf{2 0 0 5 - 2 0 0 6}$ & $1102 \times 8020$ & 4466348 & 40.5 \\
\hline $\mathbf{2 0 0 9 - 2 0 1 0}$ & 14624990 & 6080373 & 41.6 \\
\hline
\end{tabular}

Source: University Grants Commission,

(1)Basic facts and Figures, 1995-96 to 2000-2001

(2)Annual Reports (relevant years). 
The enrolment of women in higher education has consistently increased over the entire period. The percentage figures giving female share out of total have also increased consistently for the period. But despite the increase it must be realized that the figures for numbers as well as for the share out of the total were very low in the year 1975-76. Only 595162 females were enrolled in 1975-76 for higher education and their share out of total was abysmally low at 24.5 i.e., less than a quarter.

In 2009-10 female enrolment increased to 6080373 with a percentage share of $41.6 \%$, thus indicating vast improvement in the figures but still disparity exists and the male figures are better than female figures. From the above it may be inferred that enrolment numbers as well as percentage share have increased more in the post liberalization period for women.

Table 3(b) provides figures for compound rate of growth for the pre-liberalization (1975-76 to 199091) period and the post liberalization (1990-91 to 2009-10) period. The data informs positive growth in both the periods and also higher growth in enrolment for the post liberalization period. The information suggests that liberalization of the economy has been beneficial for female education at higher level also

Table 3 (b)

Compound Rate of Growth of Women Enrolment in Higher Education

\begin{tabular}{|c|c|}
\hline $\begin{array}{c}\text { Pre-Liberalization } \\
\text { (1975-76 to 1990-91) }\end{array}$ & $\begin{array}{c}\text { Post-Liberalization } \\
(\mathbf{1 9 9 0 - 9 1} \text { to 2009-10) }\end{array}$ \\
\hline $6.2 \%$ & $8.1 \%$ \\
\hline
\end{tabular}

Source: Computed from Table 3(a)

For a closer look at enrolment of females in higher education in the era of economic liberalization faculty wise data are provided from the year 1996-97 to 2009-10 in table 4. For the year 1996-97 the maximum enrolment for females was in arts with a percentage share of $41.5 \%$. The maximum percentage share was in education, which was equal to $47.4 \%$. The percentage share for medicine was also high at $40.6 \%$. The percentage shares for science, commerce/management were moderate. The percentage shares were low for veterinary Science, law, agriculture and engineering and technology. For the year 1999-2000 again the highest enrolment figures for females were in arts and maximum, percentage share for females was in education. Like 1996-97 the lowest female enrolment was in agriculture. The figures for rest of the fields demonstrated similar trend, however the figures for the year 1999-2000 were better than 1996-97 figures.

For the year 2002-03 again enrolment for females in arts was highest in numerical terms and percentage share figures for females in education were highest at $50.6 \%$ showing a marginal improvement. The percentage share figures for medicine were again at third place with $44.7 \%$ and that of agriculture were the lowest. Number wise enrolment was lowest in veterinary science. For the years 2005-06 and 2009-10 the percentage share figures for education were still the maximum, however, unlike earlier it was not arts but medicine which occupied the second place and thus pushing arts to the third place in terms of percentage share of females in enrolment. Agriculture like earlier years was at the bottom with lowest percentage share of females in enrolment. The veterinary science was again at the bottom in terms of numbers of female enrolment.

Thus from the above it can be said that arts is the first choice and veterinary science the last for females as enrolment numbers indicate in the table. As far as the percentage share of female enrolment is concerned education was at the top and agriculture at the bottom. For medicine also the percentage share for females was reasonably high. In engineering and technology the percentage share figures remained low throughout like law, agriculture and veterinary science. Arts, science and commerce/management occupied the top three positions respectively in terms of enrolment suggesting that females still prefer or are forced to prefer traditional fields of study.

The table 4 also provides compound growth rate figures for different fields. The total enrolment figures indicate an overall growth of $6.7 \%$ for all fields. However, the maximum growth is observed for engineering/technology which is equal to $13.2 \%$ suggesting an increase in interest for the field among female students. This could well be on account of recent changes in demand in the IT sector.

The minimum growth figures apart for others category is for veterinary science at $4.1 \%$. For arts and agriculture the growth rate figures are around $6 \%$. For medicine the growth rate is $8.1 \%$ suggesting popularity of the subject among females. For science, commerce/management the growth figures are around $7 \%$. Thus it can be concluded that though arts, science and commerce still remain the top three choices for females but now it seems that change in preference towards medicine and engineering/technology has started which would certainly help females in the professional and technical employment. 


\section{Stock of Female Degree Holders in India}

Higher education in general is necessary for women if they have to get good jobs. For that not merely enrolment but completion of the course is also equally important. The table 5(a) provides information about the same in both the general and technical category.

The table informs that the total stock of female degree holders increased during the period 1981 to 2001 along with the percentage share, hence a reduction in discrimination against females was observed overtime.

In the urban sector the number and percentage share for technical graduates and more qualified females was lower than non technical female graduates and more qualified women for the census years 1981, 1991, 2001. This meant that females were discriminated against more in matters of technical education than nontechnical education which is definitely not good for their employment prospects in professional and technical labour market. The only positive thing was that a declining trend in discrimination against females was observed for the entire period for both technical and non-technical education.

Within technical category in the urban sector the highest numbers of females were found in the teaching category with more than 50 percent share for the years 1981, 1991 and 2001, with percentage share increasing throughout the period 1981 to 2001, thus suggesting higher number of female degree holders than male degree holders for teaching. However, except for teaching there was wide spread discrimination against women in all other technical disciplines. The lowest numbers of female degree holders were in veterinary with very low percentage share figures. The figures for agriculture were also very low. The figures for medicine and engineering and technology were relatively higher as compared to other fields. The percentage share figures apart from teaching were higher for others category and medicine showing lower discrimination in those fields. The increase in numbers of female degree holders and their percentage share was seen in all fields for the period 1981 to 2001, thus indicating reduction in bias during the period 1981 to 2001 in the urban sector. For the rural sector the number and percentage share of female degree holders was very low. The percentage share of rural females came down significantly while it increased slightly for urban females. The percentage share figures for total females also decreased slightly. Thus, the discrimination against rural females significantly increased.

Table 4

Faculty wise Enrolment of Females in Higher Education (1996-97 to 2005-06)

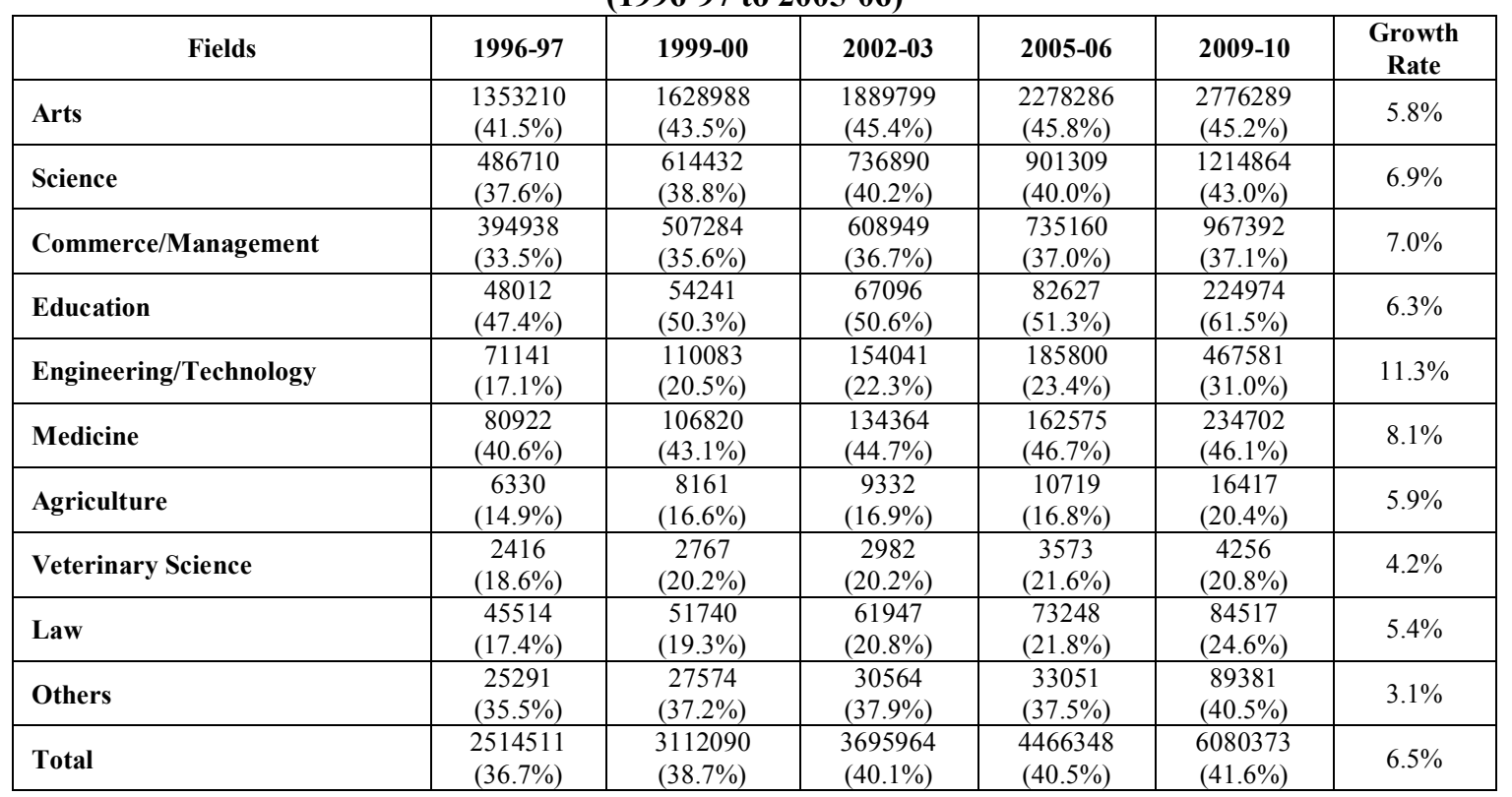

Note: The share of female to total is given in parentheses.

Source : 1. University Grants Commission,

(i) Basic facts and Figures, 1995-96 to 2000-01,

(ii) Annual Reports, (relevant years). 
Table 5 (a)

Stock of Female (General and Technical) Degree Holders in India (1981-2001)

\begin{tabular}{|l|c|c|c|c|c|c|}
\hline \multicolumn{1}{|c|}{ Region/Educational Field } & \multicolumn{2}{c|}{ 1981 } & \multicolumn{2}{c|}{$\mathbf{1 9 9 1}$} & \multicolumn{2}{c|}{ 2001 } \\
\hline Urban & Females & $\begin{array}{c}\text { \% } \\
\text { Share }\end{array}$ & Females & $\begin{array}{c}\text { \% } \\
\text { Share }\end{array}$ & Females & Share \\
\hline Non-tech. graduate and above & 1708949 & 29.4 & 4132746 & 33.3 & 8389986 & 38.3 \\
\hline Technical graduate and above & 296759 & 27.5 & 624132 & 30.9 & 110774 & 30.5 \\
\hline Engineering and technology & 7369 & 2.2 & 65268 & 9.3 & 412172 & 19.6 \\
\hline Medicine & 49438 & 21.8 & 99560 & 26 & 200018 & 32.7 \\
\hline Veterinary & 285 & 3.6 & 2761 & 17.6 & 2545 & 14.1 \\
\hline Agriculture and dairying & 1033 & 3.8 & 5600 & 14 & 5872 & 10.5 \\
\hline Teaching & 237947 & 50.5 & 444375 & 52 & 476353 & 58.7 \\
\hline Others & 687 & 31.4 & 6568 & 26.7 & 4814 & 34.8 \\
\hline Both tech and non-tech & 2005708 & 29.1 & 4756878 & 33 & 9491760 & 37.2 \\
\hline Rural & & & & & & 2645079 \\
\hline Both tech and non-tech & 312183 & 12.7 & 1080432 & 17.4 & 21.8 \\
\hline Total (Urban+Rural) & 2317891 & 24.8 & 5837310 & 28.3 & 12136839 & 32.2 \\
\hline
\end{tabular}

Source: Census of India (Various Years)

For non-technical diploma or certificate not equal to degree, the number of females for total, rural and urban were very low and the percentage share figures for all categories were also very low, especially for the rural females showing all pervasive discrimination against females.

For technical diploma or certificate not equal to degree though the numbers of females were higher for total, rural and urban category in comparison to earlier category, the percentage share figures for all categories were abysmally low. The category recorded the lowest percentage figures and highest discrimination against females. The discrimination was found a little more for the rural sector for the technical and non technical fields in comparison to urban sector. But here also the increasing trend in percentage share was noticed.

The table 5(b) gives the compound rates of growth of female degree holders for the pre-liberalization period (1981-1991) and post liberalization period (1991-2001). The table informs that the growth rates for those two periods were higher for the rural sector which is certainly a positive sign for higher education of rural females. The other point which the growth rate figures highlight are that the growth rates for the total, rural and urban sectors for female degree holders are lower in the post liberalization period which is certainly not good and requires for special efforts in this area as higher education in general and technical education in particular for both the rural and urban sector women is necessary if women are to compete with men in the labour market.

Table 5 (b)

Compound Rate of Growth of Female (General and Technical) Degree Holders in India

\begin{tabular}{|c|c|c|}
\hline SECTOR & $\begin{array}{c}\text { Pre-Liberalization Period } \\
(\mathbf{1 9 8 1 - 1 9 9 1 )}\end{array}$ & $\begin{array}{c}\text { Post Liberalization Period } \\
\text { (1991-2001) }\end{array}$ \\
\hline TOTAL & $9.6 \%$ & $7.6 \%$ \\
\hline RURAL & $13.2 \%$ & $9.4 \%$ \\
\hline URBAN & $9.1 \%$ & $7.1 \%$ \\
\hline
\end{tabular}

Source: Computed from Table 5(a)

\section{Concluding Remarks}

The above analysis clearly established the fact that on the whole women are discriminated against in attainment of higher education in general and professional and technical education in particular and the discrimination against women in the rural sector is more than the urban sector. The process of economic liberalization and globalization has also not helped the cause of female education rather the situation has worsened for females in the post liberalization period.

For tackling the problem a sound educational infrastructural base especially for professional/ technical/vocational courses is required with special consideration for women. Increasing the numbers of colleges exclusively for women would also be required. Moreover, it would also have to be ensured that such institutions which are exclusively for women should offer professional and technical courses. The increase in the enrolment for females in the professional and technical field has also to be ensured which would require incentives for female education in form of fee rebates, free education and special scholarships for female students (Sinha, 2009). Importance to female technical education can be provided by reserving seats for them in 
professional and technical courses. Further efforts should be made for educating the parents so that they realize the importance of female education especially in this era of globalization and liberalization when things are changing really fast. This would certainly require a complete overhaul of the education policy so as to make it more responsive for female education with special consideration for the rural sector females keeping in view their relative backwardness. However, the permanent cure of the problem lies in the changed attitudes of the people towards the womenfolk and this can only take place by educating the masses.

\section{References}

[1]. Appleton, S,P. Collier and P. Horsnell (1990), "Gender, Education and Employment in Cote d'Ivoire", Social Dimensions of Adjustment in Sub-Saharan Africa, Working paper No.8, World Bank, Washington D.C.

[2]. Chanana. K., (2007), "Globalisation, Higher Education and Gender Changing Subject Choices of Indian Women Students", Economic and Political Weekly, Feb.17, pp. 590-598.

[3]. Clarke, J.R. (1996), "Educational Equity in Higher Education : An International Perspective” in G.D. Postle et al. Toward Excellence and Diversity : Educational Equity in the Australian Higher Sector in 1995 : Status, Trends and Future Directions, USQ Press, Queens land.

[4]. Kingdon G.G. (1997), "Labour Force participation, Returns to Education and Sex-Discrimination in India". The Indian Journal of Labour Economics, Vol. 40, No.3, pp. 507-526.

[5]. Marginson, S. (2000), "Research As a Managed Economy : The Costs in T Coady" (ed), Why Universities Matter : A Conversation about Values, Means and Directions, Allen and Unwin, Sydney.

[6]. Nayyar, D. (2007), “Globalisation : What Does It Mean for Higher Education?” Economic and Political Weekly, Dec. 15, 2007, pp. 30-35.

[7]. Sahni, R and V.K. Shankar (2012), "Girls' Higher Education in India on the Road to Inclusiveness: On track but Heading where ", Higher Education, 63(2), pp. 237-56.

[8]. Sinha, A. (2009), "Gender Discrimination in Education and Employment”, Bharat Book Centre, Lucknow. 